\title{
Safety or Liberty?: The Bogus Trade-Off of Cross-Deputization Policy
}

\author{
Liana Maris Epstein* and Phillip Atiba Goff \\ University of California, Los Angeles
}

The discussion of cross-deputization (mandating that police officers enforce immigration policies) is often framed as a referendum on civil rights and racial politics. Those who oppose cross-deputization often maintain that asking police to target individuals based on their immigration status endangers civil rights. Those who support cross-deputization, on the other hand, argue that enforcing immigration laws is necessary to maintain a culture of lawfulness and to preserve public safety. Previous research on the psychology of legitimacy and procedural justice, however, suggests that this is likely a false dichotomy (e.g., Alpert \& Dunham, 2004; Jost \& Major, 2001; Tyler \& Huo, 2002), a perspective we adopt in this article. Drawing on the psychological literature on legitimacy and on our own research in the area of policing and immigration, we find that ensuring civil rights -and the perception of police fairness - does not conflict with public safety in either perception or reality. Rather, the public's belief in the fairness of law enforcement is a necessary precondition of public safety and lawfulness. In other words, because law enforcement requires legitimacy to be effective, wide-ranging concerns about racism actually become a threat to public safety. Implications for public policy are discussed.

"Those who would give up Essential Liberty to purchase a little Temporary Safety deserve neither liberty nor safety."

\section{-Benjamin Franklin}

\footnotetext{
* Correspondence concerning this article should be addressed to Liana M. Epstein, Department of Psychology, University of California, Los Angeles, 1285 Franz Hall, Box 951563, Los Angeles, CA, 90095 [e-mail: LMEpstein@ucla.edu].

This research was funded thanks to the support of: the Russell Sage Foundation, the UCLA Institute for American Cultures, the Society for the Psychological Study of Social Issues, and the National Science Foundation. We were invaluably aided in the development of our survey by: Mike Arnow, Ken Jameson, Kim Korinek, Theresa Martinez, and a number of other political figures, police officers, and community organizers in Salt Lake City. We would like to thank Tony Yapias for his assistance in recruiting Latino survey respondents, as well as our outstanding community surveryors in Salt Lake City: Ali Fletcher, Sondra Hansen, Mirjam Hug, Tattiya Kliengklom, and Flor Olivo. We would also like to thank the Salt Lake City Police Department, and particularly Chief Burbank, for their openness and steadfast support of equity-related research.
} 
Debates that pit civil rights against public safety have become increasingly common in the United States since the attacks of September 11, 2001 (cf. Pew Research Center, 2003). In a CNN poll conducted the day after the attacks, 66\% of Americans stated that they would be willing to "give up some of their liberties" to better crack down on terrorism. The logic of this trade-off is that the ends justify the means - that the maintenance of safety is so important that it trumps the preservation of liberty. This dichotomy dominates recent discourse in the domain of police involvement in immigration policy enforcement-a practice known as cross-deputization. The trade-off in this domain becomes whether crossdeputization negatively impacts civil rights for the sake of public safety and, if so, which is more important to the health of our nation. In this paper, we review research on the psychology of legitimacy and procedural justice that suggests this dichotomous framework (public safety vs. civil rights) is inappropriate, and worse, misleading.

We suggest that public safety and civil rights are firmly intertwined. Past research demonstrates that when an institution is perceived as biased, that institution pays a cost in the legitimacy the public affords it (Tyler, 2006). More specifically, in the domain of policing, when an officer or department loses legitimacy in the eyes of the public, they also lose community compliance with the law and cooperation in the shared goal of reducing crime (Tyler \& Fagan, 2008; Tyler \& Huo, 2002; Tyler \& Wakslak, 2004). In other words, when a police department is seen as unfair, they also become less effective, which makes the community less safe. Thus, the maintenance of civil rights is in the direct interest of public safety.

How is it, then, that the debate over cross-deputization seems to pit civil rights against public safety? To answer this question, we review the dominant arguments in favor of and against cross-deputization. Additionally, we investigate what the research literature has to say about the role of civil rights in public safety, with a particular eye toward new findings in the domain of cross-deputization and the perception racial bias. Finally, we offer suggestions regarding how the debate might be framed in the future and where there is space for scholars to provide meaningful data on this hot-button issue.

\section{Cross-Deputization and Public Safety}

Cross-deputization allows municipal law enforcement to police federalimmigration infractions. It was introduced as an option for municipal law enforcement by a federal initiative in 1996, as Section 287(g) of the Immigration and Nationality Act. Cross-deputization remained largely ignored, however, until after September 11, 2001, when issues of immigration and public safety surged to the forefront of U.S. political consciousness (cf. Pew Research Center, 2003). For example, in 2008 alone, 24 new police departments became 287(g) compliant, cross-deputizing their officers (U.S. Department of Homeland Security, 2008). 
Recently, this push for cross-deputization has received substantial public attention due to the passage of Arizona Senate Bill 1070 (SB 1070). SB 1070 has a variety of components, one of which is the institution of mandatory crossdeputization throughout Arizona. Nevertheless, though SB 1070 is a more extreme version of the $287(\mathrm{~g})$ provision and differs from $287(\mathrm{~g})$ initiatives in important ways (e.g., SB 1070 would make immigration violations a state crime, while 287 (g) programs rely on federal jurisdiction regarding immigration policy), the case of Arizona is not an isolated incident. For example, in February 2008, the Utah state legislature passed a bill similar to SB 1070, Utah Senate Bill 81 (SB 81), which encouraged (rather than required as in the case of Arizona) that Utah police and sheriff departments begin taking on immigration enforcement duties. In other words, though SB 1070 has brought cross-deputization policy to the forefront of political consciousness in the United States-it is not a new idea.

From the outset, law enforcement's engagement in immigration enforcement duties was framed as a public safety concern. The focus of 287(g) was to reduce terrorism and criminal activity of "foreign-born criminals" and "immigration violators" through the force multiplier of using local law enforcement to ferret out these criminals (U.S. Department of Homeland Security, 2008). The rationale for this initiative on the part of the U.S. government was that increased cooperation between local and federal law enforcement organizations would ease the burgeoning caseload of the badly overburdened Immigration Services (IS) department and thus, allow fewer foreign criminals to slip through the cracks in the system (U.S. Department of Homeland Security, 2008).

This particular concern with the criminality of immigrants is based on the belief that immigrants (particularly those coming over the border from Mexico) contribute disproportionately to crime and generally degrade the quality of life in a community. For example, a variety of Arizona politicians have maintained that undocumented immigrants are responsible for hundreds of brutal beheadings in the desert, despite the fact that no coroner in Southern Arizona who handles such cases has reported seeing a single case of decapitation (Davenport \& Meyers, 2010). Additionally, the governor of Arizona has stated, "We all know that the majority of the people that are coming to Arizona and trespassing are drug mules" (Alfano, 2010). In light of these claims, cross-deputization is cast as the shield with which Americans can protect themselves against the perceived influx of foreign-born criminals.

However, these assertions of the hypercriminality of immigrants, and Latino immigrants in particular, are inconsistent with a wide range of publicly available data (cf. Immigration Policy Center, 2008a; Immigration Policy Center, 2008b). Scholars seem to have reached a consensus on the fact that Mexican-Americans evidence lower levels of violence than other ethnic groups, and first-generation immigrants evidence even lower levels of violent crime (Sampson, 2006). In fact, immigration appears to be related to decreases in crime over time (Ousey \& Kubrin, 
2009). In our own analysis of publically available crime data from 2004 to 2008 in Salt Lake City, we have found that despite a rapidly increasing Latino population, Latinos continue to commit both drug and violent crimes at a rate slightly less than their proportion (28\%) of Salt Lake City's total population (Epstein \& Goff, 2010a). That is, if Latinos comprise roughly $28 \%$ of Salt Lake City's population (though this is likely a low estimate, because it does not account for all of the undocumented Latino residents), we would expect Latinos to commit roughly $28 \%$ of the crimes. This, however, is not the case. Latinos commit only $26 \%$ of the crimes that take place in Salt Lake City, indicating, again, that stereotypes of hypercriminality are unfounded. ${ }^{1}$ Thus, despite public sentiment to the contrary, a wide range of statistical evidence demonstrates that police focus on immigrants provides limited (if any) public-safety benefits.

In contrast to cross-deputization supporters, the opposition to crossdeputization makes little mention of publicsafety concerns. Instead, opposition to cross-deputization is largely concerned with the protection of civil rights (e.g., Weissman, Headen, \& Parker, 2009) and presents these rights as being of greater significance than public safety. The basis of this civil rights argument is that cross-deputization unfairly and excessively targets a particular population and, consequently, results in racial profiling (e.g., Weissman, Headen, \& Parker, 2009). In the following section, we explore whether there is any basis for these claims of racial bias.

\section{Cross-Deputization and Racial Bias}

We begin our discussion of cross-deputization and racial bias with an examination of the language of SB 1070 itself, as it has become the lightning rod for allegations of racial bias in immigration policy. SB 1070 requires that "where reasonable suspicion exists that the person is an alien who is unlawfully present in the United States, a reasonable attempt shall be made [by municipal law enforcement personnel], when practicable, to determine the immigration status" (SB 1070, 111051-B). This builds on federal legal code Title 8, Chapter 12, Section 1304(e), which requires that all "aliens" (noncitizens) carry identification papers, with failure to do so a misdemeanor punishable by a small fine. Again, the difference between SB 1070 and previous federal laws is that, under SB 1070, immigration violations become violations of state laws in addition to federal laws.

Moreover, given that officers have only their "reasonable suspicions" with which to identify undocumented immigrants, it is possible this will create a differential in who is being asked for this identification. In Arizona, over $70 \%$ of

\footnotetext{
${ }^{1}$ It is worth noting that this is a conservative test of crime participation. That is, while the documented population of Salt Lake City is $28 \%$ Latino, there is likely a sizeable undocumented population. Consequently, Latino criminality is likely significantly less (as compared to their representation in the population) than the current numbers reveal.
} 
immigrants are of Latin-American origin (U.S. Census Bureau, 2006). Given that roughly two-thirds of Arizona's immigrants are Latino, it is likely that at least twothirds of undocumented immigrants are Latino. Thus, some people are concerned that if officers were to question based on "reasonable suspicion," those who appear to be Latino will be questioned more often, given the immigrant population, causing disparate treatment of even legal Latino citizens.

The association between Latino and undocumented immigration has the potential to become an automatic linkage. Just as Black faces have been shown to evoke expectations of criminality (e.g., Eberhardt, Goff, Purdie, \& Davies, 2004; Payne, Jacoby, \& Lambert 2002), it is possible that Latino faces will evoke expectations of "illegality." There are a variety of characteristics about the policing context that will likely amplify this phenomenon. For example, time limits on decision making are associated with deficits in integrating individuating information (Pratto \& Bargh, 1991), especially among those who are busy during the category activation phase (Gilbert \& Hixon, 1991). Thus, the speed demanded by policing could lead to an increase in stereotyping and heuristic processing. This is not necessarily due to any racial bias on the part of the officers, but simply to the heuristics that they use to cope with the situational demands placed on them.

The government of Arizona anticipated that allegations of racial bias would arise from SB 1070 and went to great lengths to ensure that racial bias would not leak into the implementation of the policy. To this end, they released a training video to all Arizona police departments, as well as to the general public, that detailed how the law would be enforced. This video (available at: http://agency.azpost. gov/video/index.html) goes to great lengths to emphasize that race is not a basis for suspicion and that Arizona will not tolerate any racial profiling. Instead, the video provides an extensive list of alternative cues for undocumented status. These include: being around other illegal aliens or in location illegal aliens are known to frequent; wearing layers, long sleeves, or other clothes not consistent with climate; being in a heavy vehicle packed with people trying to hide; looking out of place, lost, or uncomfortable. Opponents of cross-deputization policy, however, will argue that these too are proxies for ethnic identification. These guidelines depict a nervous-looking person standing on the side of the road wearing multiple layers of clothing - or crammed into a van looking uncomfortable. Opponents will argue that this is much more likely to be the profile of a Mexican immigrant than, for example, a Swedish immigrant. Thus, although these behavioral cues to immigrant status may have some basis in reality, they would still target an ethnic group.

A preliminary survey with 69 college undergraduates (Epstein \& Goff, 2010b) has confirmed these suspicions. Respondents were presented with prompts that mirrored the guidelines set out in the Arizona police training video for spotting undocumented immigrants based on nonracial cues. First, respondents were presented with the text, "Eight nervous looking men are crammed into a car. They 
are wearing multiple layers of clothing and seem generally out of place." These respondents were then asked what ethnicity they thought these men were. On this free response question, $53 \%$ of respondents stated that these men were Hispanic, Latino, or Mexican. Next, the same participants were presented with the text, "A policeman pulls the car over for running a stop sign. When the policeman walks up to the car he notices that all of the men are avoiding eye contact and cannot give him a straight answer about their address. The policeman becomes suspicious that these men may be undocumented immigrants." Participants were then asked to assign likelihood percentages that the men were members of 4 different racial categories (Black, Asian, White, and Latino), with the percentages totaling to $100 \%$. On average, respondents ascribed a $52 \%$ chance that the men in the car were Latino. Thus, these results were consistent across prompts, and were unaffected by the race or gender of the respondent. Most importantly, the language in the above descriptions was taken directly from the Arizona training video's example of nonracial cues to pinpointing undocumented immigrants, but they were still perceived as racially charged by respondents.

\section{Racial Bias and Public Safety}

When a community perceives a police department to be racist, the perceived legitimacy of that department suffers (Tyler \& Huo, 2002). Communities form opinions about the legitimacy of their police based on the way that the police are seen to wield authority (Tyler \& Huo, 2002). Thus, if the community perceives their police department as illegitimate for any reason (e.g., enforcing racist laws), this negatively impacts their levels of respect for and compliance with the police (Tyler \& Fagan, 2008; Tyler \& Wakslak, 2004). Our research (Epstein \& Goff, 2010c) suggests that requiring the police to act as immigration officers has a detrimental effect on police legitimacy. Moreover, this effect was found with White community members, who only weakly endorse the idea that cross-deputization will have a detrimental impact on the Latino and immigrant communities.

This discontent with cross-deputization policy stems not only from the racial disparity in who is likely to be asked for identification papers, but also from who is making the request for these papers. Again, Section 1304(e) of Title 8 of U.S. Federal code stipulates that any "alien" who does not have identification papers on hand can be found guilty of a misdemeanor. In the past, however, the person who would be requesting that the noncitizen produce these papers would be an IS officer. Under a policy of cross-deputization, the person most likely to make this request is a municipal law-enforcement officer. Regardless of whether or not the officer believes the law is just, laws such as Arizona's SB 1070 would make it a crime for an officer not to investigate individuals that she or he suspected of being in the country illegally - a suspicion that may rest disproportionately on racial stereotypes. 
The police are sensitive to the views of the communities they serve; if the community perceives its police department as racist, the police will be cognizant of this view. Our previous research with police officers in Salt Lake City demonstrates that officers are aware that cross-deputization will affect levels of prejudice and discrimination against Latinos or immigrants and that they will be seen as racist for acting in accordance with the law (Goff et al., 2010). Moreover, officers express concern about being seen as racist as a result of having to enforce immigration laws. This concern is a form of stereotype threat-the concern one feels of being evaluated in terms of a negative stereotype about one's group (Steele \& Aronson, 1995). For instance, a woman may feel concerned that if she does poorly on a math exam, someone may suspect that she has done poorly because she is a woman. In the case of police officers, the stereotype of being racist is salient, a stereotype that can profoundly alter expectations about cross-group interactions (Goff, Steele, \& Davies, 2008).

Stereotype threat has been shown to negatively affect performance in the intergroup context (Goff, Steele, \& Davies, 2008), and is likely true in the domain of policing. People who feel stereotyped tend to report a great deal of negative affect, as a result (Vorauer, Main, \& O'Connell, 1998). Specifically, our research has shown that perceptions of racism have real implications for both how the police are viewed and how the police do their jobs (Goff et al., 2010). The perception that police are racist for acting as immigration officers has ramifications for the way in which that community views law enforcement. These perceptions induce an increased level of stereotype threat in the police, who are concerned about being seen as racist. Though this increase is particularly severe for those officers who believe that cross-deputization is a racist policy, increases in stereotype threat are observed regardless of personal beliefs (Goff et al., 2010). Additionally, this stereotype threat spurred by cross-deputization is related to a variety of negative impacts, such as: decreased job satisfaction, increased anxiety toward Latino suspects, and a sense of danger when approaching Latino suspects (Goff et al., 2010). Thus, even among those who support the policy of cross-deputization, there is real anxiety about the damage its enactment will do to public perception of law enforcement and, consequently, to the ability of police to do their jobs effectively.

The officer's conundrum is further complicated by the history of racial mistrust between non-White communities and law enforcement. From the Zoot Suit Riots of the 1940s, where White servicemen violently targeted Mexican-American youths (aided, many historians have claimed, by active duty police), to the mass deportations of Mexican Americans by police in the 1950s, to contemporary raids on immigrant communities, Latinos in the United States have witnessed generations of conflict with municipal law enforcement (Culver, 2004; Dunn, 2007; Escobar, 1999). This history may explain why Latinos (and Blacks) are less persuaded by public discourse surrounding immigration and criminality (Higgins, Gabbidon, \& Jordan, 2008). And, much like African Americans, this history of 


\section{Willingness to Report Future Crimes}

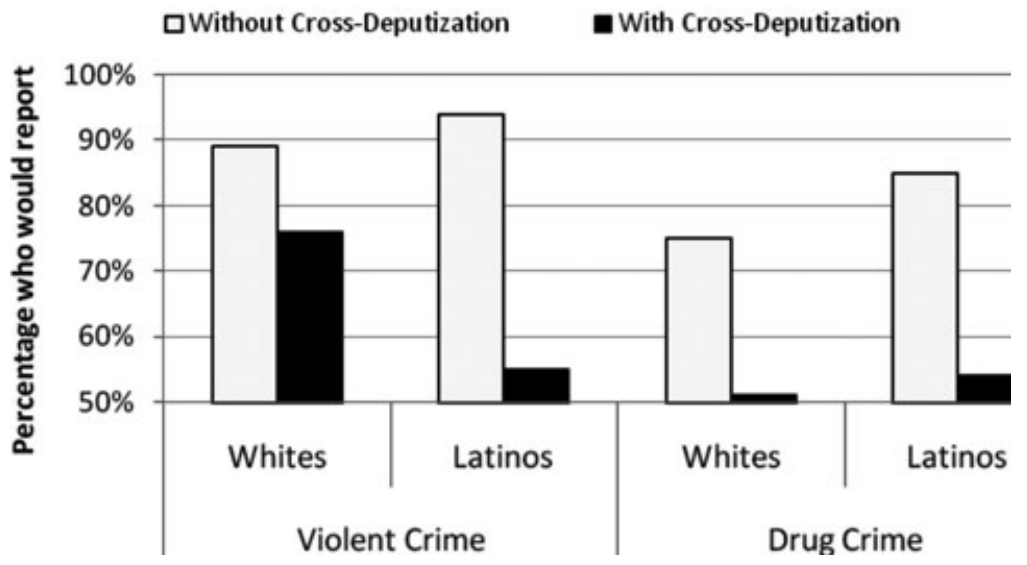

Fig. 1. Projected willingness of Salt Lake City residents to report crimes in the future with and without a policy of cross-deputization in place. Responses are reported by the type of crime and the ethnicity of the respondent.

mistrust can lead to wide gaps in perceptions of police legitimacy and the likelihood that an individual will cooperate with an officer. Importantly, this may have little or nothing to do with the behaviors of a given officer-or even a given department. Law enforcement has long been tasked with defending laws that violate civil rights (Higgins, Gabbidon, \& Jordan, 2008; Reitzel, Rice, \& Piquero, 2004). Consequently, any evidence that police are engaging in racially disparate policing stands to reduce perceptions of police legitimacy. The suggestion that police will be required to engage in racial profiling is, therefore, likely to make an already wary population all the more concerned with the possible abuses of power among law enforcement-as previous data indicate (Alpert \& Dunham, 2004; Goff, Epstein, Burbank, \& Keesee, 2009; Tyler \& Huo, 2002).

This distrust is likely to have negative consequences for the safety of all facets of the community, not only Latinos, but also Whites and the police themselves. For example, we asked White and Latino residents of Salt Lake City how likely they would be to report a variety of crimes if SB 81 were to be enacted (Goff, Epstein, Burbank, \& Keesee, 2009). Both Whites and Latinos say that they would be significantly less likely to report both drug and violent crimes if SB 81 were in place (see Figure 1). This decrease in crime reporting would likely be detrimental to public safety because it allows criminal activity to transpire unchecked.

Police officers are sensitive to the threat that cross-deputization poses to officer safety. Our research has demonstrated that regardless of their personal beliefs about immigration policy, officers are concerned that enforcing immigration laws will cost them both public respect and personal safety (Goff et al., 2010). Moreover, 
the officers' perceptions of public respect are highly correlated with their level of personal safety. This is likely due to the fact that respect from civilians is critical to an officer maintaining control in any civilian contact, maintaining the civility of any given interaction and, most importantly, minimizing the chances that force becomes necessary (Tyler \& Huo, 2002). This underlying assumption of police officers' "moral authority" is often what allows for the peaceful resolution of conflicts between law enforcement and civilians (Waddington, 1992; Waddington, 2007). However, when a policy is enacted that officers believe their community will disrespect them for enforcing, this jeopardizes the officers' moral authority.

Stripped of this moral high ground, officers feel more vulnerable, more physically unsafe, and less satisfied with their jobs (Goff et al., 2010; Waddington, 1992). Our own research (Goff et al., 2010) has shown that when cross-deputization decreases how safe officers feel approaching Latino suspects, it also decreases how satisfied they are with their jobs. Additionally, officers reported that they would be less satisfied with their jobs if cross-deputization were to be enacted. This decrease was particularly pronounced for non-White officers. The data also indicated that non-White officers would be more likely than White officers (2.4 versus 1.9 on a 5-point scale) to quit their job if a policy of cross-deputization were to be instituted. This is serious cause for concern because non-White officers are often called upon to play crucial liaison roles within their own racial and ethnic communities. Moreover, these non-White officers will be even more vital as a means of defusing concerns of racial bias if cross-deputization policies do go into effect in the future. Given that many law-enforcement agencies already report difficulty recruiting and retaining non-White officers (Walker, 2005), they cannot afford any more obstacles in the recruitment and retention of non-Whites.

In summary, we should be concerned that cross-deputization is perceived as racist, because such a perception has negative ramifications for police legitimacy and, consequently, for public safety. Safe communities are of tantamount importance, and cross-deputization is likely a threat to that priority. Though our own data is based on forecasting and self-report, the effect sizes are strong, and the picture that they paint is bleak. The combination of mounting officer dissatisfaction and decreased crime reporting would likely impair both crime prevention and criminal investigation.

\section{Conclusions and Implications}

In this paper, we have presented theoretical and empirical evidence that concerns about civil rights do not trump public safety—but instead ensure public safety. This is a break from the most common framework for understanding immigration policy that establishes public safety and civil rights as diametrically opposed concerns-that one must be chosen at the expense of the other. In the context of cross-deputization, we have shown there is little evidence that this 
policy would increase public safety, while delineating mounting evidence that this policy would create the perception (if not the reality) of racial (anti-Latino) bias. This perceived bias in cross-deputization policy would taint the legitimacy of the police in the eyes of the community, a grave development given that illegitimacy has been shown consistently to undermine the relationship between the community and the police, rendering the police less effective. Thus, the maintenance of police legitimacy is essential to the maintenance of public safety, and the most effective way to maintain legitimacy is not to enact a policy that forces officers to infringe upon the civil rights of their community members. In summary, in the domain of immigration policy, emerging data suggest that champions of civil rights and public safety should not be working at cross-purposes. These two concerns are intrinsically bound together, not diametrically opposed to each other.

\section{References}

Alfano, S. (2010, June 26). Arizona immigration debate heats up with Gov Jan Brewer saying most illegal immigrants smuggle drugs. NY Daily News. Retrieved October 9, 2010, from http://www.nydailynews.com/news/national/2010/06/26/2010-06-26_arizona_ immigration_debate_heats_up_with_gov_jan_brewer_saying_most_illegal_immi.html.

Alpert, G. P., \& Dunham, R. (2004). Understanding police use of force: officers, suspects, and reciprocity. New York: Cambridge University Press.

Culver, L. (2004). Adapting police services to new immigration. New York: LFB Scholarly Publishing.

Davenport, P., \& Meyers, A. L. (2010, September 4). Ariz. governor says she was wrong about beheadings. AP News. Retrieved October 9, 2010, from http://www.thefreelibrary.com/ Ariz.+governor+says+she+was+wrong+about+beheadings-a0161231862.

Dunn, W. (2007). Gangs of Los Angeles. Lincoln, NE: iUniverse.

Eberhardt, J. L., Goff, P. A., Purdie, V. J., \& Davies, P. G. (2004). Seeing black: Race, representation, and visual perception. Journal of Personality and Social Psychology, 87, 876-893.

Epstein, L. M., \& Goff, P. A. (2010a). The criminality of "the other" and the push for cross-deputization. Manuscript in preparation.

Epstein, L. M., \& Goff, P. A. (2010b). Unpublished manuscript.

Epstein, L. M., \& Goff, P. A. (2010c). Sound policy or symbolic racism?: Unpacking the public push for cross-deputization. Manuscript in preparation.

Escobar, E. (1999). Race, police, and the making of a political identity. Berkeley and Los Angeles, CA: University of California Press.

Gilbert, D. T., \& Hixon, J. (1991). The trouble of thinking: Activation and application of stereotypic beliefs. Journal of Personality and Social Psychology, 60, 509-517.

Goff, P. A., Epstein, L. M., Burbank, C., \& Keesee, T. L. (2009). Deputizing discrimination: Causes \& effects of cross-deputization policy in Salt Lake City, Utah. Consortium for Police Leadership and Equity.

Goff, P. A., Epstein, L. M., Jackson, M. C., Kliengklom, T. J., Gamson-Smiedt, M., \& Keesee, T. L. (2010). "Safe Because We Are Fair": How cross-deputization undermines police officer and community safety. Consortium for Police Leadership and Equity.

Goff, P. A., Steele, C. M., \& Davies, P. G. (2008). The space between us: Stereotype threat and distance in interracial contexts. Journal of Personality and Social Psychology, 94, 91-107.

Higgins, G. E., Gabbidon, S. L., \& Jordan, K. L. (2008). Examining the generality of citizens' views on racial profiling in diverse situational contexts. Criminal Justice and Behavior: An International Journal, 35, 1527-1541.

Immigration Policy Center (2008a). Immigrants and crime: are they connected? A century of research finds that crime rates for immigrants are lower than for the native-born. 
Retrieved from: http://www.immigrationpolicy.org/just-facts/immigrants-and-crime-are-theyconnected-century-research-finds-crime-rates-immigrants-are

Immigration Policy Center (2008b). From anecdotes to evidence: setting the record straight on immigrants and crime. Retrieved from http://www.immigrationpolicy.org/just-facts/anecdotesevidence-setting-record-straight-immigrants-and-crime

Jost, J. T., \& Major, B. (Eds.) (2001). The psychology of legitimacy: Emerging perspectives on ideology, justice, and intergroup relations. New York: Cambridge University Press.

Ousey, G. C., \& Kubrin, C. E. (2009). Exploring the connection between immigration and violent crime rates in U.S. cities, 1980-2000. Social Problems, 56, 447-473.

Payne, B. K., Jacoby, L. L., \& Lambert, A. J. (2004). Memory monitoring and the control of stereotype distortion. Journal of Experimental Social Psychology, 40, 52-64.

Pew Research Center for the People and the Press (2003). The 2004 Political Landscape: Evenly Divided and Increasingly Polarized. Retrieved October, 1, 2010, from http://peoplepress.org/report/?pageid=758.

Pratto, F., \& Bargh, J. (1991). Stereotyping based on apparently individuating information: Trait and global components of sex stereotypes under attention overload. Journal of Experimental Social Psychology, 2, 26-47.

Reitzel, J., Rice, S.K., \& Piquero, A.R. (2004). Lines and shadows: Perceptions of racial profiling and the Hispanic experience. Journal of Criminal Justice, 32, 607-616.

Sampson, R. J. (2006). Open doors don't invite criminals. New York Times.

Steele, C. M., \& Aronson, J. (1995). Stereotype threat and the intellectual test performance of African Americans. Journal of Personality and Social Psychology, 69, 797-811.

Tyler, T. R. (2006). Why people obey the law: Procedural justice, legitimacy, and compliance. Princeton: Princeton University Press.

Tyler, T. R., \& Fagan, J. (2008). Legitimacy and cooperation: Why do people help the police fight crime in their communities?. Ohio State Journal of Criminal Law, 6, 231-275.

Tyler, T. R., \& Huo, Y. J. (2002). Trust in the law: encouraging public cooperation with the police and courts. New York: Russell Sage Foundation.

Tyler, T. R., \& Wakslak, C. J. (2004). Profiling and police legitimacy: Procedural justice, attributions of motive, and acceptance of police authority. Criminology, 42, 253-281.

U.S. Census Bureau (2006). 2006 American community survey. Retrieved from http://factfinder. census.gov/servlet/DCGeoSelectServlet?ds_name=ACS_2006_EST_G00_.

U.S. Department of Homeland Security (2008). Delegation of Immigration Authority Section 287(g), Immigration and Nationality Act. Retrieved from http://www.ice.gov/partners/287g/ Section287_g.htm.

Waddington, D. P. (1992). Contemporary issues in public disorder: A comparative and historical approach. New York: Routledge.

Waddington, D. P. (2007). Policing public disorder: Theory and practice. Portland, Oregon: Willan.

Walker, S. (2005). The new world of police accountability. Thousand Oaks, CA: Sage Publications.

Weissman, D. M., Headen, R. C., \& Parker, K. L. (2009). The policies and politics of local immigration enforcement laws. North Carolina: American Civil Liberties Union.

LIANA MARIS EPSTEIN is a doctoral candidate in Social Psychology at the University of California, Los Angeles. She received her undergraduate degree in Psychology from Yale University. Her main research interest is in the intergroup dynamics surrounding policing and immigration.

PHILLIP ATIBA GOFF is an assistant professor in the Department of Psychology at the University of California, Los Angeles. He received his PhD in Social Psychology from Stanford University. His main research interest is in the contextual explanations that produce racial inequalities. 